\title{
出行时耗约束下的大都市区空间尺度研究 基于国内外典型案例比较
}

\section{Study on Reasonable Spatial Scale of Metropolitan Area in the Perspective of Travel Time: Based on the Comparison of Typical Cases at Home and Abroad}

摘要：国内超大城市已进入都市区发展阶段，但相关理论却相对滞后，研究我国 都市区的空间尺度问题有利于科学地制定城市政策, 预留规划设施, 促进都市 区健康发展。本文从出行时耗角度入手, 分析归纳国外发达国家都市区发展历程 与当前特征, 结合京沪等都市区发展现状及通勤时耗特征, 研判我国大都市区空 间尺度问题。研究结论证实我国大城市都市区空间拓展应以轨道交通为主要支撑 方式, 小汽车模式虽然出行效率较高, 但边际成本较高, 不适合我国城市高强度 开发特点。在轨道网络化条件下, 从出行时耗的角度, 提出都市区内单程最长 通勤时耗不应超过 1.5 小时, 采用地铁或市域铁路制式支撑空间拓展最大半径在 40 60 km 范围内, 超大城市都市区范围在 $7000 \mathrm{~km}^{2}$ 左右, 特大城市都市区范围 在 $3500 \mathrm{~km}^{2}$ 左右。为压缩出行时耗, 提高通勤效率, 应加强交通与用地系统耦 合开发, 提高接驳系统规划设计水平, 整体提高出行链组织效率, 保证出行时耗 最小化。

Abstract: Megacities of China have entered the development stage of metropolitan area (MA), meanwhile related theory is relatively lagging. Studying the spatial scale of MA is helpful for making scientific city policy, reserving facilities resources, and ensuring the healthy development of MA. From the perspective of travel time, development process and current characteristics of MA in developed countries are analyzed, combined with present situation and characteristics of commuting time of Beijing MA and Shanghai $\mathrm{MA}$, the space dimension of MA is studied under the condition that rail network is to be completed. Railway should be used to support MA spatial development in China. Although the efficiency of car travel is relatively higher, the marginal cost is also higher, which is not suitable for China. In the context of using subway or regional railway system to support the expansion of MA, one-way commuting time should be no more than $1.5 \mathrm{~h}$, the maximum radius of MA is $40 \sim 60 \mathrm{~km}$, the scale of super MA is roughly around $7000 \mathrm{~km}^{2}$, and extra MA is around $3500 \mathrm{~km}^{2}$. In order to improve commuting efficiency, land use system development should be strengthened. It is vital to improve the planning and designing level of interchange system and raise the organization efficiency of the whole trip chain.

关键词：城市规划；大都市区；出行时耗；通勤效率；市域铁路

Keywords: Urban Planning; Metropolitan Area; Travel Time; Commuting Efficiency; Regional Railway

\section{引言}

大都市区（Metropolitans Area）是城市化发展 到高级阶段时的一种空间地域形式, 在美国、日本、 德国等发达国家, 大都市区由于承载大量的经济社 会活动, 在国家经济社会序列中有重要的地位, 发 达国家多将其作为重要的地域统计单元进行研究分 析, 对于都市区概念有官方或学术组织权威的界定 标准 ${ }^{[1,2]}$ 。在国内学术界, 对大都市区概念及其界定 标准的理解却十分混乱, 对此, 一些文献 ${ }^{[3-5]}$ 进行了 专题研究, 大部分学者认为经济中心、经济腹地及 经济联系是城市功能区域的三个基本特征 ${ }^{[3-7]}$, 并在 都市区层面的区域规划中得到了应用与拓展 ${ }^{1}$ 。本 文研究的大都市区即为城市功能区域概念, 是洪世 键等研究 ${ }^{[3]}$ 结论中的最低层次, 空间尺度小于传统 认识中的都市圈概念。总体来看, 我国对大都市区 相关理论研究处于起步阶段, 对于大都市空间尺度、 规模等基础性问题, 仍缺少深人研究。与此同时, 以北京、上海为典型代表的超大城市建成区面积已 突破 $1000 \mathrm{~km}^{2}$, 行政区内常住人口超过 2000 万, 城市空间形态正向大都市区过渡, 研究大都市区的 空间尺度与规模, 有利于指导城市增长边界的划定, 进而预留重大基础设施用地、提前谋划城市发展政 策等, 有利于政府规划决策的科学化, 有较强的理 论意义及现实需求。

作者: 张沛, 西安建筑科技大学建筑学院, 教授, 博士生导师

王超深 (通信作者), 西安建筑科技大学建筑学院城乡规划学博士研究生, 注册城市规划师。409338893@qq.com

(1) 如近年来国内编制的《北京 2049 空间发展战略研究》、《成都市 2049 远景发展战略规划》、《上海总体规划 (2015一2040)》、《武汉 2049远景发 展战略》等均为都市区层面的规划。 


\section{1 大都市区形成机理及空间尺度研究进展}

\section{1 大都市区界定标准及形成机理}

(1) 大都市区界定标准

概念及标准界定是空间尺度研究的基本前提, 在都市区 的界定标准方面, 国内学者在借鉴国外都市统计区概念的基础 上, 提出了中国都市区的界定标准 ${ }^{[1-4]}$; 大多数学者利用非农 业人口、城镇人口等统计指标, 划定某阈值界定都市区范围。 总体来看, 国内学者界定都市区范围时, 选用的指标从侧面反 映了中心城区与外围地区之间的联系程度 ; 而国外都市区由于 规模基本稳定, 且有相对完善的经济及交通调查制度, 在明确 中心城市人口规模及密度的同时, 对市区与郊区之间的通勤率 指标也有严格要求 ${ }^{[3-5]}$, 相对于单纯采用人口或产业指标, 能 更加生动地反映地区之间的交流, 其标准更加科学严谨。

(2) 大都市区形成机理

大都市区的产生, 是多种因素影响的结果, 但直接影响 因素主要是城市用地的限制和交通条件的改善 ${ }^{[7-9]}$, 交通运 输技术的升级为大都市区拓展提供了外部条件, 从国外发展 历程看, 小汽车的普及和轨道交通的快速发展是大都市区形 成的必要条件。从演进历程上看, 大都市区内的中心城市与 外围腹地聚集和扩散的双向运动推动城市功能空间不断分化 和重组, 是大城市地域空间组织从简单到复杂、从低级到高 级的演变过程 ${ }^{[4]}$ 。

\section{2 大都市区空间尺度研究进展}

国内学者对于大都市区空间尺度的研究相对较少, 对于 空间范围的划分, 由于对外文文献中 “Metropolitans” 认识 不同, 多是针对都市圈 ${ }^{[1}$ 层面而言, 例如文献 ${ }^{[10-15]}$ 等。王国 霞和蔡建明归纳了国际上常见的四种界定都市区空间范围的 方法, 并以北京为例进行实证分析 ${ }^{[12]}$, 但是没有考虑出行成 本, 仅考虑出行时耗, 使得都市区范围明显增大。其他学者 研究对象名称虽然为都市圈, 但地域功能与国外界定的都市 区特征基本接近, 如陈斌和杨涛认为都市圈不同地域范围内 有不同的交通特征, 在没有轨道交通系统支撑及小汽车未普 及的情况下, 都市圈通勤半径仅为 $13 \mathrm{~km}$ 左右 ${ }^{[13]}$; 韩刚和袁 家冬利用经济距离等指标划定长春都市圈的地域范围, 平均 半径为 $57 \mathrm{~km}$, 都市圈面积约 1 万 $\mathrm{km}^{2[14]}$; 康盈等从城市功 能区域及用地特征角度分析了重庆大都市区空间层次划分, 研究结论与当前大多数学者划分层次基本一致 ${ }^{[15]}$ 。总结上述 学者关于都市圈 (区) 空间层次及尺度的研究成果, 主要结 论如表 1 所示。

\section{3 交通运输方式更新与大都市区空间拓展}

从国外大都市区空间拓展历程看, 机动化交通模式推动 城市空间的拓展一般有三种主导模式 : 以美国大都市为典型 代表的小汽车主导模式 (模式一)、以亚太及拉美城市为代 表的公共交通主导模式 (模式二)、以欧洲城市为代表的混 合型模式（模式三）（表 2)。由于大都市区空间尺度、城市 发展阶段、人口分布空间及密度特征、城市交通发展战略与 政策等诸多因素的差异性, 公共交通主导类型呈现多样化的 特征, 包括轨道绝对主导、“轨道+公交”主导、BRT 主导 三种主要模式。对于发展中国家, 轨道交通建设与大都市区

\section{表 1 我国典型都市圈（区）地域层次划分研究汇总}

\begin{tabular}{|c|c|c|c|c|c|}
\hline 作者 & $\begin{array}{l}\text { 研究 } \\
\text { 视角 }\end{array}$ & $\begin{array}{l}\text { 核心 } \\
\text { 理论 }\end{array}$ & 空间层次及规模 & $\begin{array}{l}\text { 实证 } \\
\text { 分析 }\end{array}$ & 评述 \\
\hline $\begin{array}{l}\text { 陈斌、 } \\
\text { 杨涛 }^{[13]}\end{array}$ & $\begin{array}{l}\text { 交通运 } \\
\text { 输学 }\end{array}$ & $\begin{array}{l}\text { 出行时 } \\
\text { 耗约束 } \\
\text { 理论 }\end{array}$ & $\begin{array}{l}\text { 半径 } 13 \mathrm{~km} \text { 范围内为 } \\
\text { 通勤 圈 + 半径 } 60 \mathrm{~km} \\
\text { 的日常消费圈 + 半径 } \\
120 \mathrm{~km} \text { 范围内辐射圈层 }\end{array}$ & 南京 & $\begin{array}{l}\text { 研究时间较早, 轨 } \\
\text { 道交通及小汽车未 } \\
\text { 大范围普及情况 } \\
\text { 下, 通勤圈半径明 } \\
\text { 显偏小 }\end{array}$ \\
\hline $\begin{array}{l}\text { 韩刚、 } \\
\text { 袁家冬 }{ }^{[14]}\end{array}$ & $\begin{array}{l}\text { 人文地 } \\
\text { 理学 }\end{array}$ & $\begin{array}{l}\text { 经济距 } \\
\text { 离. 引 } \\
\text { 力模型 }\end{array}$ & $\begin{array}{l}\text { 核心圈 }\left(3000 \mathrm{~km}^{2}\right)+ \\
\text { 紧密圈 }\left(2700 \mathrm{~km}^{2}\right)+ \\
\text { 机会圈 }\left(4300 \mathrm{~km}^{2}\right)\end{array}$ & 长春 & $\begin{array}{l}\text { 核心圈采用行政区 } \\
\text { 划面积, 与实际功 } \\
\text { 能区域差异较大 }\end{array}$ \\
\hline 康盈等 ${ }^{[15]}$ & $\begin{array}{l}\text { 城乡规 } \\
\text { 划学 }\end{array}$ & $\begin{array}{l}\text { 城市地 } \\
\text { 域功能 } \\
\text { 空间划 } \\
\text { 分 }\end{array}$ & $\begin{array}{l}\text { 半径 } 10 \sim 15 \mathrm{~km} \text { 用地 } \\
\text { 发展连绵区 }+ \text { 半径 } \\
20 \sim 50 \mathrm{~km} \text { 通勤圈层 }+ \\
\text { 外侧圈层 (功能联动 } \\
\text { 区) }\end{array}$ & 重庆 & $\begin{array}{l}\text { 与当前大多数学者 } \\
\text { 的研究结论基本吻 } \\
\text { 合, 研究对象位于 } \\
\text { 非平原地带, 都市 } \\
\text { 区拓展与常规平原 } \\
\text { 区有较大差异 }\end{array}$ \\
\hline
\end{tabular}

资料来源 : 根据参考文献 [13-15] 整理

表 2 基于交通出行方式的大都市区空间拓展典型模式

\begin{tabular}{|c|c|c|c|c|}
\hline 模式 & $\begin{array}{c}\text { 都市区空间拓 } \\
\text { 展模式 }\end{array}$ & 典型案例 & $\begin{array}{c}\text { 个体机动化出行 } \\
\text { 比例 }\end{array}$ & $\begin{array}{c}\text { 公共交通出行 } \\
\text { 比例 }\end{array}$ \\
\hline 模式一 & $\begin{array}{l}\text { 小汽车主导模 } \\
\text { 式 }\end{array}$ & $\begin{array}{l}\text { 洛杉矶、芝 } \\
\text { 加哥 }\end{array}$ & $\begin{array}{l}\text { 洛杉矶 }(85 \%) \\
\text { 芝加哥 }(69 \%)\end{array}$ & $\begin{array}{l}\text { 洛杉矶 }(10 \%) \\
\text { 芝加哥 }(25 \%)\end{array}$ \\
\hline \multirow[t]{3}{*}{ 模式二 } & $\begin{array}{l}\text { 轨道绝对主导 } \\
\text { 模式 }\end{array}$ & 东京 & $50 \mathrm{~km}$ 交通圈 $(35 \%)$ & $\begin{array}{c}50 \mathrm{~km} \text { 交通圈 } \\
(65 \%)\end{array}$ \\
\hline & $\begin{array}{l}\text { “轨道 }+ \text { 公 } \\
\text { 交” 主导模式 }\end{array}$ & $\begin{array}{l}\text { 香港、新加 } \\
\text { 坡、首尔 }\end{array}$ & $\begin{array}{l}\text { 香港 ( } 19 \%) \\
\text { 新加坡 (42\%) } \\
\text { 首尔 }(32 \%)\end{array}$ & $\begin{array}{l}\text { 香港 ( } 81 \%) \\
\text { 新加坡 }(58 \%) \\
\text { 首尔 }(68 \%)\end{array}$ \\
\hline & BRT 主导模式 & $\begin{array}{l}\text { 库里蒂巴、 } \\
\text { 波哥大 }\end{array}$ & $\begin{array}{l}\text { 库里蒂巴 (38\%) } \\
\text { 波哥大 }(23 \%)\end{array}$ & $\begin{array}{l}\text { 库里蒂巴 }(62 \%) \\
\text { 波哥大 }(77 \%)\end{array}$ \\
\hline 模式三 & $\begin{array}{l}\text { “公交+ 小汽 } \\
\text { 车”模式 }\end{array}$ & 巴黎、伦敦 & $\begin{array}{l}\text { 巴黎（58\%） } \\
\text { 伦敦（59\%） }\end{array}$ & $\begin{array}{l}\text { 巴黎 }(42 \%) \\
\text { 伦敦 }(41 \%)\end{array}$ \\
\hline
\end{tabular}

注: 个体机动车包括摩托车等其他两轮机动车; 出行比例中除洛杉矶、 芝加哥为全方式外, 其他均为机动化出行比例。

资料来源 : 作者整理

(1) 当前大部分学者认为都市圈范围大于大都市区, 是以大都市区为核心依托, 加上周边一系列中小城市构成的城市连绵区, 部分学者称之为城市群等。 
空间拓展处于同步发展阶段, 轨道交通具有更高的出行可靠 度和强大的时空转换能力, 近年来得到了国内外学者的广泛 关注, 多数学者将其作为都市区拓展及空间结构调整的主要 运输载体 ${ }^{[16-18]}$ 。

\section{2 国外典型大都市区空间尺度分析}

国外都市区规模及空间尺度差异较大，如北欧国家人口 密度较低, 往往以首都为核心形成都市区, 但是规模明显偏小, 基本在 200 万人左右。本文研究都市区空间尺度问题, 主要 针对中心城市建成区范围内现状人口超过 300 万人口的大都 市区, 且都市区基本位于平原地区, 有较大的人口及经济腹地。 伦敦、巴黎、纽约、东京是公认的世界级大都市区, 且都市 区人口规模进人相对稳定阶段, 作为研究对象, 归纳其内在 规律, 对于我国大都市区规划建设具有较强的借鉴意义。

\section{1 国外典型大都市区中长距离通勤出行特征与轨道网络}

大都市区空间尺度、通勤半径与城市规划政策、交通组 织模式、城市空间结构与形态等有较大关系, 伦敦及巴黎采 用了建设新城的方式疏解中心城职能，形成了多中心的空间 格局, 长距离通勤交通数量明显小于其他世界级都市区。而 东京在强大的轨道交通网络支撑下, 形成了以东京区部为极 核的东京交通圈, 通勤距离明显延长, 最大通勤半径超过 $120 \mathrm{~km}{ }^{1}$ 。同时也存在明显的共性, 伦敦、巴黎、纽约及东 京四大都市区空间拓展与其发达的轨道交通网络密不可分, 在半径 $70 \mathrm{~km}$ 左右的空间范围内, 拥有各类制式轨道总里程 分别为 $3070 \mathrm{~km} 、 2075 \mathrm{~km} 、 1620 \mathrm{~km} 、 2175 \mathrm{~km}^{[19-22]}$, 轨网 密度明显高于我国特大及超大城市都市区规划值, 四大都市 区轨道网络布局如图 1 所示。

\section{2 国外典型大都市区通勤出行特征}

(1) 伦敦都市区

目前, 伦敦都市区范围包括大伦敦范围外围的远郊城镇,
面积约 $10385 \mathrm{~km}^{2}$, 以通勤交通为口径统计外围地区居民至 内伦敦的出行结构, 小汽车及班车比例为 $66 \%$, 平均出行时 耗为 32 分钟; 国铁分担率为 4\%, 平均出行时耗为 67 分钟 ${ }^{[22]}$ 。 小汽车在伦敦都市区外围的空间拓展中起重要的支撑作用, 尤其是在内伦敦之外的区域, 距离中心城区距离越远, 小汽 车分担率越高。大伦敦外围地区城市建设并没有沿轨道线路 展开, 且人口密度相对较低, 国铁等轨道方式在城区外围与 小汽车相比, 不论在通勤时间还是服务水平等各方面均没有 明显优势, 这是欧洲大都市空间拓展模式与亚太地区城市存 在较大差别的地方 ${ }^{[24,25]}$ 。

(2) 巴黎都市区

巴黎大都市区（即大巴黎）与伦敦都市区相比, 城市建 设空间相对紧凑, 巴黎新城距离中心城区的距离也明显小于 伦敦, 根据 2010 年大巴黎地区交通调查结论, 大于 $10 \mathrm{~km}$ 的远距离出行所占总出行量的比例为 $14 \%$, 大于 $20 \mathrm{~km}$ 距离 的比例仅为 5\%, 其中基于工作出行的比例为 49\% ${ }^{[26]}$, 客观 说明了法国新城建设效益较高, 就地实现职住平衡比例较高。 巴黎都市区拓展中, 近 $600 \mathrm{~km}$ 的市域铁路 RER 与城市轨道 网络紧密地衔接在一起, 有力地支撑了新城发展及都市区空 间拓展。

\section{（3）纽约都市区}

纽约都市区（即纽约都市统计区）是美国少有的以公共 交通为主要机动化运输方式的城市, 根据 2009 年美国社区调 查数据显示, 纽约市居民通勤交通出行采用公交车、地铁和 区域铁路三种方式的比例达到 55\%。纽约都市区范围内, 小 汽车和公共交通平均通勤距离分别为 11.47 英里和 11.34 英里 (1 英里约为 $1.6 \mathrm{~km}$ ), 两者基本接近, 但是小汽车平均出行 时耗仅为 28.04 分钟, 公共交通平均出行时耗为 58.07 分钟, 小汽车出行服务品质明显高于公共交通。在纽约市区, 尤其是 曼哈顿区实行严格的交通需求政策, 使得进出该区域的交通方 式呈现以公共交通为主体的特点。根据测算, 通勤铁路承担的 通勤交通比例约在 $4 \%$ 左右, 主要通勤范围在 $50 \mathrm{~km}$ 内 ${ }^{[27]}$ 。

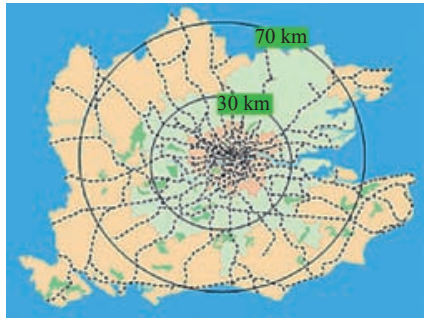

伦敦

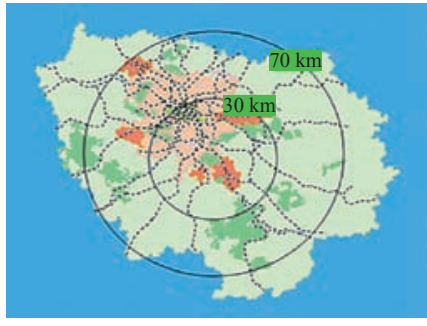

巴黎

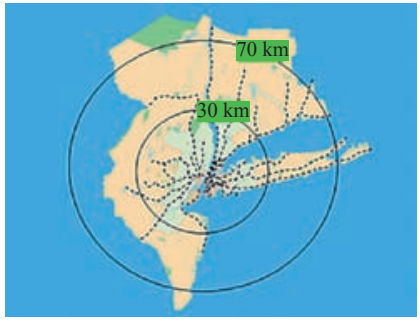

纽约

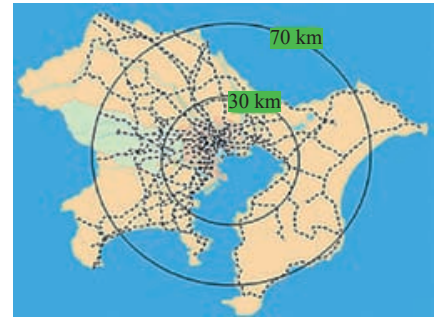

东京

图 1 世界四大都市区轨道线网布局图 资料来源 : 参考文献 [23]

(1) 根据日本总务省统计局平成 17 年国势调查, 在东京大都市圈范围内最长通勤距离近 $130 \mathrm{~km}$, 但人数极少。 


\section{(4) 东京都市区}

东京都市区（以 $70 \mathrm{~km}$ 交通圈范围为研究对象）是世界 四大都市区中规模最大, 也是外围地区至中心城区通勤特征 最为明显的都市区。从行政地域范围看, 横滨、川崎、埼玉、 千叶四市至东京区部就业人口为 92 万人, 占四市总就业人 口的 34.8\% ; 从就业者的空间分布看, 2005 年东京区部 669 万就业者中 $85 \%$ 居住在距离东京站 $30 \mathrm{~km}$ 的范围内, $13 \%$ 居住在 30 50 km 范围内, $2 \%$ 居住在 $50 \mathrm{~km}$ 以外。从通勤时 间来看, $44 \%$ 的乘客出行时间在 60 89 分钟之间, 单程时间 超过 2 小时的乘客占 $7.9 \%$ 。虽然通勤距离较长, 但是受益 于东京高效的轨道交通网络, 基于轨道的单程通勤时间平均 为 68.7 分钟, 与伦敦、巴黎等都市区接近 ${ }^{[18]}$ 。

\section{3 国外典型大都市区空间尺度与通勤特征研究结论}

(1) 国外典型大都市区空间尺度

从发达国家大都市区发展历程来看, 都市区形态与规模进 人相对稳定期, 伦敦、巴黎都市区空间范围达到 1 万 $\mathrm{km}^{2}$ 左右, 现状人口约 1200 万; 纽约、东京都市区空间尺度较大, 达到 1.7 万 $\mathrm{km}^{2}$ 左右, 现状人口分别为近 2000 万和 3700 万 (表 3)。

（2）国外典型大都市区通勤半径

从通勤时耗及半径看, 四大都市区外围地区受益于发达 的轨道交通网络, 至中心城区以上班为目的的居民平均出行 时耗基本在 60 70 分钟, 通勤半径大都在 50 70 km 范围内, 东京都市区较为发达的 JR 系统也承担部分通勤职能, 使得 都市区空间半径明显大于其他几个大都市区（图 2)。

（3）国外典型大都市区通勤特征

四大都市区, 超过 $30 \mathrm{~km}$ 的远距离出行主要依靠市域铁 路、通勤铁路或其他轨道制式实现, 尤其是进人中心城区的

“向心性”通勤交通几乎均由轨道交通实现, 且交通换乘系 统效率较高, 最长出行时耗一般控制在 70 分钟之内; 而在 都市区外围由于没有实现严格的交通需求管理政策, 道路容 量较大, 小汽车更有竞争力, 是 “非向心性” 交通的主要出 行方式。

\section{3 我国大都市区的空间尺度研判}

\section{1 大都市区长距离主导通勤方式研判}

我国城镇化过程是典型的时空压缩式发展模式, 城市空 间拓展与交通机动化同步, 具有开发强度高、人口规模大等 特点, 都市区空间拓展规律与国外案例相比, 略有差异。例 如, 当前我国轨道制式中没有严格意义上的市域铁路和城市 快轨, 常规的国铁系统基本不承担通勤交通职能, 现阶段我 国都市区空间拓展以长度无限延伸的地铁、使用成本较低的 小汽车、服务水平低下的常规公交为主要支撑方式, 是以牺 牲通勤者的休憩时间换取的。从世界都市区发展历程看, 这 种方式只是短期内的权宜之计, 在城镇化进入提质阶段后, 居民对出行服务质量要求越来越高, 以牺牲交通时间换取城

\section{表 3 国外典型大都市空间尺度及出行时耗指标}

\begin{tabular}{|c|c|c|c|c|c|}
\hline 城市 & $\begin{array}{c}\text { 都市区 } \\
\text { 范围 } \\
\left(\mathbf{k m}^{2}\right)\end{array}$ & $\begin{array}{l}\text { 人口 } \\
\text { (万人) }\end{array}$ & $\begin{array}{l}\text { 市域铁路 } \\
\text { 分担率 }{ }^{1}\end{array}$ & $\begin{array}{c}\text { 平均通 } \\
\text { 勤时耗 } \\
\text { (min) }\end{array}$ & $\begin{array}{c}\text { 最大通勤 } \\
\text { 半径 } \\
(\mathbf{k m})\end{array}$ \\
\hline 伦敦大都市区 & 10385 & 1195 & $4 \%$ & 66 & 60 \\
\hline 大巴黎大区 & 12011 & 1149 & $2.5 \%$ & 73 & 50 \\
\hline 纽约都市统计区 & 17400 & 1975 & $\approx 4 \%$ & 58 & 50 \\
\hline 东京交通圈 $(70 \mathrm{~km})$ & 16382 & 3760 & $15 \%^{(3)}$ & 69 & 70 \\
\hline
\end{tabular}

注: 进入中心城区的统计概念伦敦指内伦敦 $\left(319 \mathrm{~km}^{2}\right)$, 巴黎为近郊区 $\left(657 \mathrm{~km}^{2}\right)$, 纽约为纽约市 $\left(790 \mathrm{~km}^{2}\right)$, 东京为区部 $\left(622 \mathrm{~km}^{2}\right)$ 。 资料来源 : 根据参考文献 [20-29] 整理

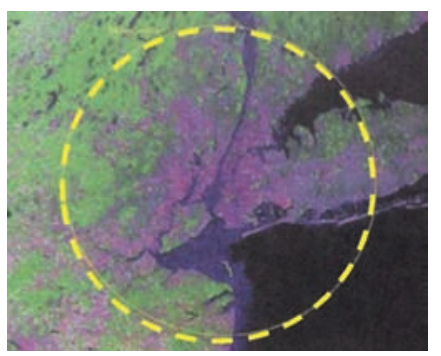

纽约

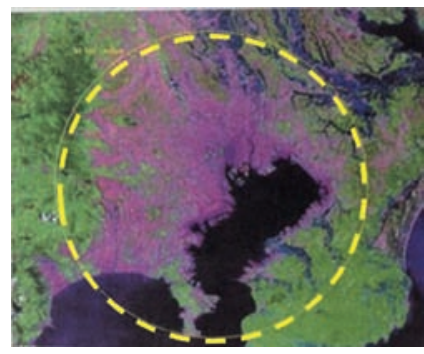

东京

图 2 世界四大都市区空间尺度 (半径 $50 \mathrm{~km}$ ) 资料来源 : 根据参考文献 [30] 绘制

(1) 为研究方便, 将大伦敦都市区范围内具有通勤职能的国铁系统、大巴黎地区的 RER、东京交通圈内的 JR 和私铁等、纽约都市统计区内的通勤铁路 统称为市域铁路。市域铁路分担率是指从外围地区至中心城区使用市域铁路的通勤交通量占外围地区居民各类出行目的总出行量的比例。

(2) 表中通勤半径以各国规定通勤率阈值为判断标准给出的最长通勤半径, 由于外围新城通勤率指标与距离中心区距离关系并非呈现线性负相关关系, 导致该值是满足通勤率阈值对应值域范围内的最大值。由于都市区范围并非规整的几何图形, 若以通勤半径最大值划定一圆形, 其值一般会大于 都市区实际范围值。巴黎及纽约都市区分别为行政及经济统计区范围, 与基于通勤交通的划分方式有一定出入。

(3) 该数字假定 $30 \mathrm{~km}$ 以上通勤人口至区部交通方式均为轨道交通。 
市发展的模式将不可持续。

同时，随着城市骨架的明显增大，在没有实施全面的交 通需求管理背景下, 城市道路网络拥堵将更加严重, 基于常 规路网的出行可靠度不稳定性明显增加, 与此同时, 大城市 轨道网络系统不断完善, 大都市空间拓展依赖的主要交通方 式将由小汽车向轨道交通方式过渡 ${ }^{1}$ 。尤其是交通拥堵成为 常态的中心城区, 以通勤交通为目的的轨道交通方式分担率 不断提高, 我国绝大多数特大城市及超大城市交通结构目标 中明确轨道交通在机动化方式中的分担率不低于 $50 \%$, 轨道 交通将是大都市空间拓展的主要交通方式。

\section{2 出行时耗与通勤效率}

通勤时间是决定人居尺度的首要要素，城市道路交通规 划设计规范（GB50220-95）在机动化尚未普及的情况下, 规 定大于 200 万人的城市单程出行时耗应控制在 60 分钟内。 但是随着城市空间的急剧扩张及路网饱和度的明显增大, 我 国特大城市及超大城市居民单程出行时耗已明显延长。2010 年, 南京外围新城单程通勤时间超过 1 小时的占 $28.2 \%{ }^{[31]}$; 2005 年北京市远郊区至中心城区单程出行时耗为 112.9 分 钟 ${ }^{132}, 2010$ 年基于地铁的平均出行时间为 75 分钟, 北京市 2014 年展开的第五次居民出行调查, 初步结论显示外围地区 基于地铁的出行时耗在 90 分钟左右; 2009 年上海市中心城 区就业人员单程出行时耗超过 80 分钟的比例已超过 $13 \%{ }^{[33]}$ 。 由此可见, 在轨道里程明显增加及网络化的背景下, 居民出 行距离也有了明显增长, 加之接驳换乘系统不够紧密, 出行 时耗也明显增长。对于大都市区而言，从通勤效率及国外都 市区发展历程看, 最大出行时耗应控制在 90 分钟之内, 扣 除起论点两端接驳时间, 在轨道列车上通行时间约为 60 分 钟左右 ${ }^{[34,351}$, 以此测算不同轨道制式在不同运营条件下都市 区合理空间尺度问题。

\section{3 经济运距与轨道制式}

近年来，轨道制式呈现多样化的特征，除服务城区的地 铁、轻轨系统外, 国内出现了城市快速轨道交通的概念, 如 上海 16 号线，设计车速为 $120 \mathrm{~km} / \mathrm{h}$, 站间距为 $4.9 \mathrm{~km}$, 与 传统概念中的市域铁路基本接近; 同时, 国内也有市郊铁路 的概念, 它在既有铁路基础上改建或新建线路, 设计车速更 高、站间距更大, 如上海金山铁路设计车速达到 $160 \mathrm{~km} / \mathrm{h}$, 站间距 $6.3 \mathrm{~km}$; 成都成灌铁路设计车速达到 $200 \mathrm{~km} / \mathrm{h}$, 站间 距 $5.6 \mathrm{~km}$ 。现阶段, 轨道线路与沿线土地没有实现同步开发, 且受票价较高、两端接驳系统不紧密、走廊内出行方式选择
多样化等原因影响, 基于市域铁路的通勤交通特征不够明显, 如不进行改善, 短期内难以成为都市区拓展的主要运输方式。

综上所述，在通勤距离明显增加及轨道制式多样化的背 景下, 居民出行选择的通勤范围是综合考量各因素后, 选择 的可接受的空间尺度，不仅仅是一个 “技术距离” 更是一个

“经济距离”, 没有外部经济补贴的条件下, 利用高铁、城 际铁路等大容量国铁系统承担 $30 \mathrm{~km}$ 以下通勤交通的概率较 低。而市域铁路经济运距是 20 60 km，与都市区空间尺度 基本吻合, 若能与站点周边用地进行联合开发, 将是最契合 都市区拓展的轨道交通方式。

\section{4 基于轨道方式的我国大都市区空间尺度研判}

我国都市区规模较大, 考虑轨道网络化程度、与用地系 统耦合及换乘组织效率等因素, 对外交通枢纽普遍受 “大广 场、大枢纽” 等理念影响, 结合当前特大城市交通出行调查 结论, 笔者认为我国都市区远期基于轨道出行方式, 大多数 出行者在两端接驳时间在 15 20 分钟之间, 以此值分别测算 不同轨道制式在不同运行速度下, 都市区最大通勤半径。如 表 4 所示, 依靠常规的地铁系统, 在运行方式无改进的情况 下, 都市区最大通勤半径能达到 $40 \mathrm{~km}$ 左右, 但是单程总计 出行时耗在 2 小时左右, 出行效率较低; 若在城区外围采用 大站快线的运营方式, 在单程总计出行时耗 1.5 小时内, 通 勤半径也可达到 $40 \mathrm{~km}$, 通勤效率明显提高, 但运营方式在 国内鲜见, 面临较大挑战。若采用市域铁路的方式, 通勤半 径可达到 40 60 km, 且出行时耗保证在 1.5 小时内, 通勤效 率较高, 从这一角度看, 市域铁路将是支撑都市区空间拓展 的有效运输方式。

总体来看, 都市区空间拓展与交通运输方式存在显著 的关系, 与居民可接受的出行时耗存在约束关系, 基于不 同轨道制式的都市区空间尺度，在居民可接受的出行时耗 内, 最大通勤半径在 40 60 km 之间, 此范围与当前我国主

表 4 基于出行时耗约束条件的我国大都市区空间尺度估算

\begin{tabular}{l|l|l|l|l|l|l}
\hline 轨道制式 & $\begin{array}{c}\text { 站间距 } \\
(\mathbf{k m})\end{array}$ & 运营方式 & $\begin{array}{l}\text { 运行速度 } \\
(\mathbf{k m} / \mathbf{h})\end{array}$ & $\begin{array}{c}\text { 行程时耗 } \\
\text { (小时 })\end{array}$ & $\begin{array}{l}\text { 通勤半径 } \\
(\mathbf{k m})\end{array}$ & $\begin{array}{l}\text { 通勤 } \\
\text { 效率 }\end{array}$ \\
\hline \multirow{2}{*}{ 地铁 } & $0.8 \sim 1.5$ & 站站停靠 & $25 \sim 35$ & $1.2 ~ 1.5^{*}$ & $37 \sim 42$ & 低 \\
\cline { 2 - 7 } & $1.5 \sim 2$ & 大站快线 & $35 \sim 40$ & $1.0 \sim 1.2$ & $40 \sim 42$ & 高 \\
\hline 市域铁路 & $2 \sim 3$ & 站站停靠 & $40 \sim 50$ & $1.0 \sim 1.2$ & $42 \sim 50$ & 较高 \\
\cline { 2 - 7 } & $3 \sim 5$ & 站站停靠 & $50 \sim 60$ & $0.8 \sim 1.0$ & $50 \sim 60$ & 高 \\
\hline
\end{tabular}

注: *表示, 在地铁网络发达、站点密度较大的地区, 接驳时间相对较 短, 在地铁列车上出行时间将略微增加。

资料来源 : 作者整理

(1) 大多数学者认为受经济因素、城市交通容量空间等影响, 亚太国家大都市区空间拓展过程中, 小汽车难以成为长距离通勤交通的主要方式。 
要特大城市及超大城市划定的都市区范围或城市规划区基本 吻合。如表 5 所示, 北京总规划定的都市区范围及上海市域 范围基本在 $7000 \mathrm{~km}^{2}$ 左右; 成都、武汉等城市划定都市区 范围在 $3500 \mathrm{~km}^{2}$ 左右; 沈阳市总规划定的城市规划区范围 具备都市区基本特征, 可看作都市区范围, 空间范围亦接近 $3500 \mathrm{~km}^{2}$; 在平原或浅丘地区较大的副省级城市为中心城 市形成的都市区, 以中心城区为圆心测算其空间半径基本在 $30 \mathrm{~km}$ 左右。

\section{5 国内外大都市区空间尺度差异比较分析}

与国外典型大都市区相比, 我国大都市区空间尺度明 显偏小, 京沪等超大城市都市区范围仅有国外同类型规模的 $1 / 2$ 左右, 这与我国长期以来实行 “紧凑、高强” 的土地开 发模式有较大关系, 从交通系统支撑的角度看, 市域铁路的 层级缺失, 也变相加剧了我国大都市区建设用地呈现出 “连 续、紧凑、高强”的空间形态。

纽约、东京等国际大都市的市域铁路系统, 基本在 1940 年代以前建成骨架网络, 后期在传统铁路的基础上改建或在 既有客流走廊内新建而成, 有力地支撑了远郊人口至中心城 就业。伦敦、巴黎等采用了 “飞地型” 的新城建设模式, 新 区与中心城区距离较远, 传统的地铁制式难以满足出行时耗 要求, 也促成了伦敦国铁 BR、巴黎 RER 的快速发展, 形成 了较大的空间尺度。而我国都市区拓展, 除受地形限制较为 明显的深圳、重庆等少量山地城市外, 其他大部分平原城市 基本是 “推大饼” 形态, 建设用地相对聚集与集中, 城市形 态紧凑, 中心城区一般在以旧城区为圆心、半径为 $15 \sim 20 \mathrm{~km}$ 的空间范围内, 外围组团一般在距离中心城 $30 \sim 50 \mathrm{~km}$ 的半 径范围内。虽然地铁制式最高设计速度已达到 $120 \mathrm{~km} / \mathrm{h}$, 且 已有上海 16 号线、广州 3 号线等线路的运营实践, 但是我国 大都市外围地区人口规模及密度与国外相比仍然较高, 致使 地铁站间距平均值在 $3 \mathrm{~km}$ 左右, 制约了实际运行速度的提高; 站站停靠的运营方式使得都市区外围地区地铁制式实际运行

\section{表 5 我国典型大都市区的空间范围划定}

\begin{tabular}{c|c|c|c|l}
\hline 名称 & $\begin{array}{c}\text { 都市区 } \\
\text { 范围 } \\
\left(\mathbf{k m}^{2}\right)\end{array}$ & $\begin{array}{c}\text { 空间 } \\
\text { 半径 } \\
(\mathbf{k m})\end{array}$ & $\begin{array}{c}\text { 现状 } \\
\text { 人口 } \\
\text { (万人) }\end{array}$ & \multicolumn{1}{|c}{ 都市区空间范围 } \\
\hline 北京 & 7665 & 50 & 1700 & $\begin{array}{l}2004 \text { 版 《总规》确定的核心区 +功能拓 } \\
\text { 展区+城市发展新区的总和 }\end{array}$ \\
\hline 上海 & 6340 & 55 & 2400 & 上海市行政区面积 \\
\hline 武汉 & 3261 & 30 & $880^{*}$ & 以外环高速附近的乡镇行政边界为界线 \\
\hline 成都 & 3681 & 30 & 1100 & 中心城区+紧邻中心城区的五个县市区 \\
\hline 沈阳 & 3471 & 30 & - & 《总规》划定的城市规划区范围 \\
\hline
\end{tabular}

注: * 表示, 武汉人口数据为 2020 年规划值。

资料来源 : 根据各城市总体规划汇总
速度仅能达到 $40 \mathrm{~km} / \mathrm{h}$ 左右, 与东京、巴黎等大都市采用通 勤直行、大站快线的运营方式相比, 我国城市轨道制式运行 速度明显偏低, 加之两端接驳不便, 出行链条总时耗明显延 长, 都极大地限制了都市区空间范围的拓展。

\section{4 结论与建议}

\section{1 结论}

(1) 轨道交通是我国大都市区空间拓展的主要方式

从世界范围内看, 大都市区空间拓展形成了“小汽车主 导”、“公交主导”、“混合型”三种模式, 其典型代表分别为 北美城市、亚太及部分拉美城市、欧洲城市，个体机动车在 机动化方式中的分担率比例分别在 70\% $90 \% 、 20 \% \sim 40 \%$ 、 $60 \%$ 左右。与欧美世界级都市区相比, 我国大都市区人口规 模更大、土地开发强度更高, 这些特征决定了都市区客运交 通组织只能以公共交通作为主导方式。轨道交通作为更低碳、 单位运量更高、出行可靠度更高的新型运输方式, 符合我国 都市区土地开发强度高、人流高度聚集的特点, 将是都市区 空间拓展的主要方式。

（2）超大城市形成的都市区空间范围在 $7000 \mathrm{~km}^{2}$ 左右, 依托现有的城市轨道制式通勤效率较低

北京、上海等超大城市形成的都市区空间范围在 $7000 \mathrm{~km}^{2}$ 左右, 依靠常规地铁、轻轨等城市轨道铁制式, 外围新城至中心城单程出行时耗难以保证在 1.5 小时内, 出 行效率较低。近期发展运行速度更高、站间距更大的市域铁 路系统有较强的必要性。依托这种交通方式都市区外围有利 于形成带状或组团型的空间结构, 摆脱 “摊大饼式” 形态导 致的交通流空间分布无序、组织低效的缺陷。

（3）特大城市形成的都市区空间范围在 $3500 \mathrm{~km}^{2}$ 左右, 常规城市轨道制式基本满足出行要求, 但通勤效率较低

武汉、成都等较大规模的省会城市形成的都市区, 其空 间范围在 $3500 \mathrm{~km}^{2}$ 左右, 常规地铁、轻轨等制式勉强适应 都市区拓展需求, 但牺牲了通勤者大量的休闲时间, 通勤效 率较低。该层级都市区在空间尺度、外围新城人口聚集等方 面难以达到建设市域铁路的标准, 同时由于存在体制、政策、 实施路径等障碍, 市域铁路短期内难以实质性推进。从提高 通勤效率角度看, 应着重研究通过改进运营方式, 设置大站 快线等方式压缩出行时间, 满足都市区中长距离通勤需求。

\section{2 建议}

(1) 科学的轨道线网规划是都市区高效拓展的重要保 障, 国内应加强都市区层面线网规划研究

传统的城市总体规划研究年限一般为 20 年, 研究重点 多为中心城区, 对于都市区范围研究相对薄弱; 而部分城 
市编制的城市空间发展战略等规划类型虽然明确了都市区范 围, 但不属于法定规划, 使得城市轨道线网规划在都市区层 面规划缺少法定的规划依据，加之当前地方政府“重建设、 轻规划”等原因, 使得轨网关注重点落实在中心城区层面, 造成城市轨道与区域轨道不能高效衔接。在特大城市进人都 市区发展阶段后, 应加强都市区层面轨道线网规划, 预留相 应空间资源，以高效、便捷的轨网系统支撑城市空间拓展及 都市区发展。

（2）基于出行链时间分布特征, 有效压缩单程出行时间

随着城市规模的增大和空间结构的调整，城市居民通勤 距离将会进一步增大, 而人们的“时间价值”也愈来愈明显, 都市区空间拓展中必须采取多样化措施, 压缩出行链中的各 种交通方式的出行时间, 尤其是两端的接驳时间, 使得总出 行时耗控制在 1.5 小时之内, 提高出行效率, 保证出行品质。

(3) 短期内轨道运营方式的改进可有效地支撑都市区空 间拓展

与国外大都市区轨道运营经验相比, 我国城市轨道运营 组织方式较为单一, 基本没有大站快线、直达线路等方式, 均为站站停靠服务, 单条线路运行时耗较长, 不能满足中长 距离出行者需求, 在都市区规模继续扩张的背景下, 出行效 率将继续降低。借鉴国外经验, 通过设置越行站开行大站快 线或直达线路等方式, 能够明显压缩行程时间, 在票价基本 不变的情况下, 满足中长距离居民出行时间要求, 有效地支 撑都市区空间拓展。UPI

\section{参考文献}

[1] 周一星.城市地理学 [M]. 北京: 商务印书馆, 2003.

[2] 谢守红. 大都市区的空间组织 [M]. 北京: 科学出版社, 2004

[3] 洪世键，黄晓芬。大都市区概念及其界定问题探讨 [J]. 国际城市规划, 2007, 22(5): 50-57.

[4] 谢守红.都市区、都市圈和都市带的概念界定与比较分析 [J]. 城市问题, 2008(6): 19-23.

[5]史育龙, 周一星. 关于大都市带 (都市连绵区) 研究的论争及近今进 展述评 [J]. 国际城市规划, 2009, 24(S1): 160-166.

[6] 沈洁, 张京祥.都市圈规划：地域规划的新范式 [J]. 城市问题, 2004(1): 23-27.

[7] 谢守红, 宁越敏。中国大城市的发展和都市区的形成 [J]. 城市问题, 2005(1): 11-15.

[8] 孙胤社. 大都市区的形成机制及其定界以北京为例 [J]. 地理学报, 1992, 47(6): 552-560.

[9] 易承志. 大都市与大都市区概念辨析 [J]. 城市问题, 2014(3): 90-95.

[10] 陈大鹏, 孙飞。西安都市圈空间界定的定量研究 [J]. 城市发展研究, 2012(10): 43-47

[11] 张萍, 张玉拿.上海大都市区空间范围研究 [J]. 城市规划学刊, 2013(4): 27-32.

[12]王国霞，蔡建明. 都市区空间范围的划分方法 [J]. 经济地理, 2008, 28(2): 192-195

[13] 陈斌, 杨涛.南京都市圈交通圈层演化特征实证研究 [J]. 现代城市研究, 2006(10): 45-51

[14] 韩刚, 袁家冬, 论长春都市圈的地域范围与空间结构 [J]. 地理科学,
2014, 34(10): 1202-1209.

[15] 康盈, 桑东升, 李献忠. 大都市区范围与空间圈层界定方法与技术路 线探讨一以重庆市大都市区空间发展研究为例 [J]. 城市发展研究, 2015, 22(1): 22-27.

[16] 张元浩, 荣朝和. 从时空视角看轨道交通对东京大都市区的影响 [J]. 铁 道运输与经济, 2015, 37(8): 78-82.

[17] 边经卫.城市轨道交通与城市空间形态模式选择 [J]. 城市交通, 2009, 7(5): 58-61.

[18] 刘胜龙, 杜建华, 张道海. 轨道上的世界：东京都市圈城市和交通研 究 [M]. 北京: 人民交通出版社, 2013.

[19] Coffey W. The Evolution of Canada's Metropolitan Economies[M]. Montreal Institute for Research on Public Policy, 1994.

[20] 于长明, 吴维佳, 于涛方. 特大城市地区土地利用形态一一伦敦、巴黎、 纽约、东京与北京比较 [J]. 北京规划建设, 2012(5): 8-12.

[21] Saizen I, Mizuno K, Kobayashi S. Effects of Land-use Master Plans in the Metropolitan Fringe of Japan[J]. Landscape \& Urban Planning, 2006, 78(4): 411-421.

[22] Hiley A, Rose M, Seagriff E. Delivering a New Mayor's Transport Strategy for London - A Truly Integrated Approach[C]. European Transport Conference, 2010.

[23] 刘剑锋, 冯爱军, 王静, 等。北京市郊轨道交通发展策略 [J]. 城市交通, 2014, 12(6): 28-36

[24] 毛保华, 郭继孚, 陈金川, 等. 城市综合交通结构演变的实证研究 [M]. 北京: 人民交通出版社, 2011 .

[25]田莉, 姚凯, 王伟, 等.世界著名大都市规划建设与发展比较研究 [M]. 北京: 中国建筑工业出版社, 2010.

[26] 中国城市规划设计研究院综合交通研究所. 大巴黎地区综合交通调查 报告 [R]. 中国城市规划设计研究院, 2014.

[27] 陈雪明. 纽约的公共交通系统和规划经验谈 [J]. 国际城市规划, 2015, 30(S1): 84-88.

[28] Demetra V. C, Joy S, Lee G. The 2001 National Household Travel Survey: A Look Into the Travel Patterns of Older Americans[J]. Journal of Safety Research, 2003, (34)4: 461-470.

[29] 荣朝和, 问星神. 东京大都市区轨道通勤体系的演进与功能分析 [J]. 城 市发展研究, 2015, 22(7): 16-23.

[30] 张捷, 赵民. 新城规划的理论与实践一一田园城市思路的世纪演绎 [M]. 北京: 中国建筑工业出版社, 2005 .

[31] 杨卡. 大都市郊区新城通勤行为空间研究——南京市为例 [J]. 城市 发展研究, 2010(2): 42-46.

[32] 北京交通发展研究中心. 北京市交通发展年度报告 [R]. 2005.

[33] 上海市城市综合交通规划研究所. 上海市第四次综合交通调查报告 [R]. 2010.

[34] 张育南. 轨道交通影响下的大都市空间尺度 [J]. 都市快轨交通, 2007, 20(3): $12-16$

[35] Jun M, Hui J. Commuting Patterns of New Town Residents in the Seoul Metropolitan Area[J]. Journal of The Korea Regional Development Association, 2000(2): 157-170.

(本文编辑：张祎娴) 